\title{
PERENCANAAN PULANG EFEKTIF MENINGKATKAN KEMAMPUAN IBU MERAWAT ANAK DENGAN PNEUMONIA DI RUMAH
}

\author{
Eva Yuliani ${ }^{1}$, Nani Nurhaeni ${ }^{2 *}$, Fajar Tri Waluyanti $^{2}$ \\ 1. Program Studi Magister Fakultas Ilmu Keperawatan Universitas Indonesia, Depok 16424, Indonesia \\ 2. Fakultas Ilmu KeperawatanUniversitas Indonesia, Depok 16424, Indonesia \\ *E-mail: nani-n@ui.ac.id
}

\begin{abstract}
Abstrak
Risiko terjadinya pneumonia dan meningkatnya risiko anak untuk dirawat inap adalah kurang mampunya ibu merawat anak di rumah. Penelitian ini bertujuan untuk mengidentifikasi pengaruh perencanaan pulang terhadap kemampuan ibu merawat anak pneumonia di rumah. Penelitian ini merupakan studi quasi-experiment dengan rancangan post-test only group. Sampel penelitian adalah 26 responden di dua rumah sakit di Sulawesi Barat. Hasil post-test menggambarkan tingkat pengetahuan dan keterampilan masing-masing kelompok berbeda secara bermakna $(p<0,05)$, dan ibu pada kelompok intervensi mampu merawat anak pneumonia di rumah, berbeda secara bermakna dengan kelompok kontrol ( $\mathrm{p}<0,05)$. Perencanaan pulang anak dengan pneumonia hendaknya diberikan secara terstruktur guna mendukung terlaksananya asuhan keperawatan anak yang berpusat pada keluarga di rumah sakit.
\end{abstract}

Kata kunci: kemampuan ibu, perencanaan pulang, pneumonia

\section{Abstract}

Discharge Planning Effectively Improved the Mother's Ability to Take Care of the Children with Pneumonia at Home. Pneumonia is one of the causes of high morbidity and mortality of children in Indonesia. One risk factor for pneumonia and increased risk for hospitalized children is the lack of maternal knowledge. The aim of this study was to identify the effect of discharge planning for maternal ability in caring the child with pneumonia at home. This research was a quasi-experiment study with posttest only group design. The study sample was 26 respondents in two hospitals in West Sulawesi. The result showed that the post-test level of knowledge and skills were different significantly $(p<0,05)$ between the groups. Mothers in the intervention group were found to be capable of caring for child with pneumonia, and this was significantly different to the control group $(p<0,05)$. Discharge planning about children with pneumonia should be administered to support the implementation of family-centered care in pediatric nursing at the hospital.

Keywords: discharge planning, maternal ability, pneumonia

\section{Pendahuluan}

Pneumonia merupakan salah satu masalah kesehatan dan penyebab kematian anak usia di bawah lima tahun (balita) di dunia (Nantanda, Tumwine, Ndeezi, \& Ostergaard, 2013). Di Indonesia, 23,8\% kematian bayi disebabkan karena pneumonia dan $15,5 \%$ pada balita (Depkes RI, 2007), sehingga perlu upaya kesehatan dengan melibatkan keluarga dan masyarakat.
Perawatan anak tidak terlepas dari keterlibatan keluarga terutama orang tua. Oleh karena itu, perawatan berfokus keluarga menjadi konsep utama perawatan anak selama hospitalisasi (Nurhaeni, Sutadi, Rustina, \& Supriyatno, 2011). Keluarga, khususnya ibu, merupakan orang yang paling dekat dengan anak dan diharapkan mampu merawat anak selama di rumah, memenuhi kebutuhan, menyelesaikan masalah, dan menggunakan sumber-sumber yang tepat dalam memenuhi kebutuhan kesehatan keluarga (Ferdous, et al., 2014). 
Proses perencanaan pulang seharusnya dimulai sejak pasien mendapatkan pelayanan kesehatan. Perencanaan pulang yang telah dilaksanakan selama ini kebanyakan dianggap sebagai resume pulang (Lees, 2013). Informasi yang disampaikan meliputi kapan jadwal kunjungan ulang, diet yang harus diterapkan di rumah dan tindakan terkait perawatan yang harus dilakukan di rumah (Allen, Hutchinson, Brown, \& Livingston, 2014).

Salah satu penyebab pneumonia berulang pada anak yaitu tingkat pengetahuan ibu yang rendah tentang perawatan anak di rumah (Ericson, 2012). Hal ini berdampak pada ketidakmampuan ibu dalam mencegah maupun merawat anak dengan pneumonia (Hoving \& Brand, 2013).

Banyaknya permasalahan anak dengan pneumonia membuat perawatan lanjutan di rumah harus dilakukan. Salah satu cara yang dapat dilakukan untuk menanganinya adalah dengan memberdayakan keluarga terutama ibu dalam merawat anak ketika kembali ke rumah.

\section{Metode}

Penelitian ini merupakan penelitian kuantitatif dengan desain quasi eksperiment dengan pendekatan nonequivalent control group, post test only design. Rancangan ini menggunakan dua kelompok yaitu kelompok kontrol dan kelompok intervensi. Pada kelompok kontrol dilakukan perawatan dengan edukasi rutin; sedangkan pada kelompok intervensi dilakukan intervenesi berupa perencanaan pulang yang dimulai dari pengkajian, pembuatan diagnosis, perencanaan, implementasi, dan evaluasi.
Sampel dalam penelitian ini adalah 26 ibu dan anak pneumonia yang dirawat. Sampel diambil menggunakan teknik consecutive sampling. Kriteria inklusi untuk sampel penelitian adalah: ibu dengan anak berusia 0-59 bulan, menunggui anaknya saat dirawat, mampu membaca dan menulis, dan bersedia menjadi responden; sedangkan kriteria eksklusi adalah anak yang dalam kondisi kritis. Prosedur penelitian pada kelompok intervensi dilakukan mulai dari pengkajian pada hari pertama pasien dirawat, kemudian hari kedua dilakukan perencanaan dengan membuat perjanjian untuk jadwal pertemuan edukasi tentang cara merawat yang perlu ditingkatkan, hari ketiga dan keempat dilakukan implementasi pemberian edukasi sesuai kebutuhan ibu, hari kelima dan atau pemulangan dilakukan pengecekan kembali pengetahuan tentang pemberian obat. Selanjutnya peneliti melakukan kunjungan rumah di hari kedua atau hari ketiga pasca anak pulang dari rumah sakit untuk dilakukan evaluasi kemampuan ibu merawat anak.

Penelitian ini telah lolos kaji etik dari Komite Etik Riset FIK-UI. Pengambilan data dilakukan dengan menggunakan kuesioner tentang pengetahuan, dan lembar observasi keterampilan ibu dalam merawat anak dengan pneumonia. Data dianalisis dengan menggunakan uji t dependen dan uji Chi-square.

\section{Hasil}

Karakteristik ibu yang memiliki anak dengan pneumonia diidentifikasi berdasarkan pendidikan, pengalaman merawat anak dengan pneumonia, jumlah balita yang dimiliki dan dukungan sosial. 
Tabel 1. Hubungan Variabel Perancu dengan Kemampuan Ibu Merawat Anak Pneumonia di Rumah

\begin{tabular}{|c|c|c|c|c|c|c|c|}
\hline \multirow[b]{2}{*}{ Variabel } & \multicolumn{2}{|c|}{$\begin{array}{c}\text { Intervensi } \\
\text { Kemampuan }\end{array}$} & \multicolumn{2}{|c|}{$\begin{array}{c}\text { Kontrol } \\
\text { Kemampuan }\end{array}$} & \multirow{2}{*}{$\begin{array}{c}\text { Total } \\
\mathrm{n}=\mathbf{2 6}\end{array}$} & \multirow[b]{2}{*}{ OR } & \multirow[b]{2}{*}{$\mathbf{p}$} \\
\hline & $\begin{array}{l}\text { Kurang } \\
\text { Mampu }\end{array}$ & Mampu & $\begin{array}{l}\text { Kurang } \\
\text { Mampu }\end{array}$ & Mampu & & & \\
\hline \multicolumn{8}{|l|}{ Pendidikan } \\
\hline a. Dasar & 3 & 7 & 7 & 0 & 17 & & \multirow{3}{*}{0,700} \\
\hline b. Menengah & 1 & 2 & 3 & 0 & 6 & & \\
\hline c. Tinggi & 0 & 0 & 0 & 3 & 3 & & \\
\hline \multicolumn{8}{|c|}{ Pengalaman merawat anak pneumonia } \\
\hline a. Tidak ada & 4 & 7 & 8 & 2 & 21 & \multirow{2}{*}{2,00} & \multirow{2}{*}{0,630} \\
\hline b. Ada & 0 & 2 & 2 & 1 & 5 & & \\
\hline \multicolumn{8}{|c|}{ Jumlah anak balita } \\
\hline a. $>1$ anak & 4 & 5 & 7 & 1 & 17 & \multirow{2}{*}{3,66} & \multirow{2}{*}{0,210} \\
\hline b. 1 anak & 0 & 4 & 3 & 2 & 9 & & \\
\hline \multicolumn{8}{|l|}{ Dukungan sosial } \\
\hline a. Tidak ada & 0 & 0 & 1 & 0 & 1 & \multirow{2}{*}{1,92} & \multirow{2}{*}{1,000} \\
\hline b. Ada & 4 & 9 & 9 & 3 & 25 & & \\
\hline
\end{tabular}

Tabel 2. Perbedaan Tingkat Kemampuan (Pengetahuan dan Keterampilan) Ibu Merawat Anak Pneumonia di Rumah

\begin{tabular}{|c|c|c|c|c|c|c|c|c|}
\hline \multirow[t]{2}{*}{ Variabel } & \multicolumn{2}{|c|}{$\begin{array}{c}\text { Intervensi } \\
n=13\end{array}$} & \multicolumn{2}{|c|}{$\begin{array}{c}\text { Kontrol } \\
\mathrm{n}=13\end{array}$} & \multicolumn{2}{|c|}{$\begin{array}{c}\text { Total } \\
n=26\end{array}$} & \multirow[t]{2}{*}{ OR } & \multirow[t]{2}{*}{$\mathbf{p}$} \\
\hline & $\mathbf{f}$ & $\%$ & $\mathbf{f}$ & $\%$ & $\mathbf{f}$ & $\%$ & & \\
\hline \multicolumn{9}{|l|}{ Pengetahuan } \\
\hline a. Rendah & 2 & 15,4 & 8 & 61,5 & 10 & 38,5 & 8,80 & 0,04 \\
\hline b. Tinggi & 11 & 84,6 & 5 & 38,5 & 16 & & & \\
\hline Keterampilan & & & & & & 61,5 & & \\
\hline a. Tidak terampil & 4 & 30,8 & 10 & 76,9 & 14 & 53,8 & 7,50 & 0,04 \\
\hline b. Terampil & 9 & 69,2 & 3 & 23,1 & 12 & 160 & & \\
\hline Kemampuan & & & & & & & & \\
\hline a. Kurang mampu & 4 & 30,8 & 10 & 76,9 & 14 & 53,8 & 7,50 & 0,04 \\
\hline b. Mampu & 9 & 69,2 & 3 & 23,1 & 12 & 46,2 & & \\
\hline
\end{tabular}

\section{Pembahasan}

Faktor yang Memengaruhi Kemampuan Ibu. Tingkat pendidikan responden menunjukkan tidak adanya hubungan bermakna dengan tingkat kemampuan ibu merawat anak pneumonia. Maknanya apapun pendidikan ibu tidak memengaruhi kemampuan ibu dalam merawat anak pneumonia di rumah. Hal berbeda diungkapkan oleh Redman (1993 dalam Potter \& Perry, 2006) yang menje-laskan bahwa seseorang yang berpendidikan lebih tinggi akan memberikan pengetahuan yang lebih besar, sehingga menghasilkan kebiasaan mempertahankan kesehatan lebih baik. Syahrani, Santoso, dan Sayono (2012) menyatakan pendapat yang berbeda bahwa seseorang yang berpendidikan rendah tidak berarti mutlak berpengetahuan rendah pula. Pengalaman ibu merawat anak pneumonia pada kelompok intervensi dan kelompok kontrol mayoritas tidak memiliki pengalaman yaitu $84,6 \%$ dan $76,9 \%$. Hasil analisis statistik menyimpulkan tidak terdapat hubungan bermakna antara pe- 
ngalaman merawat anak pneumonia dengan kemampuan ibu merawat anak. Hal berbeda diungkapkan Devi, Ranjana, dan Laxmi (2012) yang mengungkapkan bahwa tidak adanya pengalaman pada sebagian besar ibu memungkinkan mereka untuk bertindak tidak sesuai anjuran dalam merawat anggota keluarga yang sakit. Jumlah anak balita yang dimiliki ibu pada kelompok intervensi dan kelompok kontrol sebagian besar memiliki anak lebih dari satu. Meskipun ibu memiliki anak lebih dari satu, tetapi jika ibu mendapat dukungan dari keluarga untuk membantu merawat anaknya, hal ini tidak akan memengaruhi peran ibu dalam merawat anak yang sakit. Sama halnya dengan dukungan sosial, pada kedua kelompok responden mayoritas mendapat dukungan sosial. Namun setelah dianalisis tidak memiliki hubungan yang bermakna karena didapatkan hanya satu responden yang tidak mendapat dukungan.

Perbedaan Kemampuan Ibu yang Diberikan dengan yang Tidak Dilakukan Perencanaan Pulang. Kemampuan ibu dinilai dari pengetahuan dan keterampilan dalam merawat anak pneumonia di rumah. Ibu dinyatakan kurang mampu apabila hanya satu atau tidak ada kriteria baik pada aspek pengetahuan dan keterampilan dan dinyatakan mampu apabila memenuhi kriteria baik pada pengetahuan dan keterampilan.

Hasil penelitian menunjukkan bahwa tingkat kemampuan ibu pada kelompok intervensi lebih tinggi dibandingkan kelompok kontrol Hal ini memperlihatkan bahwa ada perbedaan yang bermakna kemampuan ibu merawat anak pneumonia pada kelompok intervensi dengan kelompok kontrol.

Hasil penelitian ini sejalan dengan penelitian Dein, Elbahnasawy, dan Diab (2013) yang menyimpulkan bahwa ada perubahan yang signifikan pada aspek pengetahuan dan praktik perawatan anak dengan infeksi saluran per- napasan oleh ibu yang dilakukan proses perencanaan pulang. Pada penelitian lain oleh Shepperd, Lannin, Clemson, McCluskey, Cameron, dan Barras (2013) menyimpulkan bahwa ada pengaruh pelaksanaan perencanaan pulang terhadap kesiapan keluarga merawat pasien di rumah. Penelitian yang dilakukan Wahyuni, Nurrachmawati dan Gayatri (2012) menyimpulkan bahwa terdapat perbedaan bermakna antara kesiapan pulang pasien Penyakit Jantung Koroner (PJK) yang diberikan perencanaan pulang dibandingkan dengan pasien yang tidak diberikan perencanaan pulang.

Responden dalam penelitian ini adalah ibu yang anaknya dirawat di rumah sakit dengan pneumonia dengan usia anak antara 0-59 bulan. Usia balita memiliki ketergantungan yang tinggi dengan orang tua sehingga kerjasama dengan orang tua selama perawatan anak sangat dibutuhkan. Keluarga khususnya ibu adalah orang yang paling mengetahui apa yang dibutuhkan oleh anak. Konsep yang mendasari asuhan yang berpusat pada keluarga adalah menfasilitasi keterlibatan orang tua dalam perawatan dan peningkatan kemampuan keluarga dalam merawat anak. Orang tua diharapkan mempunyai kesempatan untuk meneruskan peran dan tugasnya merawat anak selama di rumah sakit (Bowden \& Greenberg, 2010). Salah satu upaya yang dapat dilakukan perawat untuk memfasilitasi keterlibatan orang tua dalam perawatan anak adalah dengan melakukan perencanaan pulang secara terstruktur.

Perencanaan pulang merupakan suatu proses mempersiapkan pasien untuk mempertahankan kontinuitas dalam perawatan. Proses tersebut dimulai sejak awal pasien datang ke sebuah tempat pelayanan kesehatan (Kozier, 2005). Proses belajar dalam perencanaan pulang merupakan mekanisme pemberian informasi secara terstruktur, sehingga pasien atau keluarga lebih banyak memperoleh informasi 
dan lebih mudah dalam mencerna informasi (Morris, Winfield, \& Young, 2012).

Tujuan perencanaan pulang adalah membantu proses penyembuhan, mempertahankan kesehatan dan sekaligus mencegah terjadinya kekambuhan sampai pasien siap kembali ke rumah (Kozier, 2005). Pelaksanaan perencanaan pulang mencakup pemberian informasi kepada keluarga tentang cara perawatan anak dengan pneumonia ketika di rumah, menjadi dasar bagi keluarga untuk menindaklanjuti pelaksanaan perawatan dan pencegahan pneumonia di rumah secara mandiri.

Perencanaan pulang yang baik dapat menjamin pasien untuk mampu melakukan tindakan perawatan lanjutan yang aman dan realistis setelah meninggalkan rumah sakit (Holland, Conlon, Rohlik, Gillard, Tomlinson, et al., 2014). Apabila ibu telah memiliki kemampuan merawat anak pneumonia, ibu akan mudah bekerjasama dalam perawatan anaknya, sehingga konsep asuhan yang berpusat pada keluarga/family centered care (FCC) dapat diterapkan dan mencapai hasil asuhan keperawatan yang optimal.

Manfaat penerapan asuhan yang berpusat pada keluarga menurut American Academic of Pediatric Committee on Hospital Care (2006) adalah penggunaan sumber-sumber pelayanan kesehatan dan waktu tenaga profesional lebih efisien dan efektif (mengoptimalkan manajemen perawatan di rumah, mengurangi kunjungan ke unit gawat darurat atau rumah sakit jika tidak perlu, digunakan cara pencegahan dengan lebih efektif). Apabila asuhan yang berpusat pada keluarga dapat diterapkan dengan baik khususnya dalam perawatan anak dengan pneumonia, maka keterbatasan tenaga perawat bukan merupakan kendala untuk dapat terlaksananya asuhan keperawatan pada anak secara lebih optimal.

Pentingnya pelaksanaan perencanaan pulang sebagai upaya peningkatan kualitas asuhan keperawatan dapat dilakukan dengan cara mensosialisasikan dan menjadikan perencanaan pulang sebagai intervensi keperawatan. Perawat harus berperan dalam mempersiapkan keluarga, melalui proses perencanaan pulang dan memastikan mereka memperoleh pengetahuan dan keterampilan yang diperlukan.

Hasil penelitian menunjukkan bahwa pelaksanaan perencanaan pulang yang terstruktur dapat diterapkan di rumah sakit dan dapat dijadikan sebagai Standar Prosedur Operasional (SOP) di ruang perawatan. Pemberian edukasi dalam perencanaan pulang akan memberikan gambaran yang jelas kepada ibu apa yang harus dilakukannya ketika merawat anak pneumonia di rumah. Ibu yang memiliki pengetahuan tentang perawatan anak akan membentuk perilaku yang terampil karena memiliki kepercayaan dan keyakinan diri terhadap kemampuan melakukan serangkaian tugastugas pengasuhan anaknya.

Perawat anak mempunyai peran yang sangat besar dalam membuat perencanaan pulang yang dilakukan sejak pasien masuk rumah sakit sampai pulang melalui proses keperawatan yang diawali dengan pengkajian sampai evaluasi. Pengkajian yang dilakukan secara individual akan membantu perawat memberkan edukasi sesuai kebutuhan pasien, sehingga ibu mempunyai pengetahuan tentang perawatan anak pneumonia di rumah yang berdampak pada penurunan risiko rawat ulang pasca rawat. Perawat perlu membangun kemitraan dengan orang tua melalui komunikasi yang terbuka dan jujur untuk memberikan dukungan keluarga dengan memberdayakan keluarga untuk bertanggung jawab memberikan asuhan keperawatan yang berkesinambungan dan mendukung keberhasilan dalam perencanaan pulang.

Keberhasilan perencanaan pulang dapat diteliti lebih lanjut dengan mengkaji efektivitasnya dalam menurunkan angka kejadian rehospitalisasi anak dengan penyakit yang sama yaitu pneumonia. 


\section{Kesimpulan}

Perencanaan pulang yang terstruktur dapat meningkatkan secara bermakna kemampuan ibu yang meliputi pengetahuan dan keterampilan dalam merawat anak pneumonia di rumah. Hal ini mengindikasikan perlunya penerapan asuhan yang berpusat pada keluarga agar orang tua mampu merawat anaknya di rumah (YR, HR, AM).

\section{Ucapan Terima Kasih}

Pihak RSUD tempat penelitian dilaksanakan terutama staf pengelola ruang perawatan anak yang telah banyak membantu terlibat dalam riset dan seluruh ibu yang telah bersedia ikut berpartisipasi, sehingga penelitian ini dapat terselesaikan.

\section{Referensi}

Allen, J., Hutchinson, A.M., Brown, R., \& Livingston, P.M. (2014). Quality care outcomes following transitional care interventions for older people from hospital to home: A systematic review. BMC Health Service Research, 14, 346. doi: 10.1186/14726963-14-346.

American Academy of Pediatrics Committee on Hospital Care. (2006). Family centered care and pediatrician's role. Pediatrics, 112, 691696.

Bowden, V.R., \& Greenberg, C.S. (2010). Children and their families: The continuum of care (2nd Ed.). Philadelphia: Lippincott Williams \& Wilkins.

Dein, N.A.Z., Elbanasawy, H.T., \& Diab, S.S. (2013). The effect of guidance booklet on discharge mothers of children with respiratory tract infection. Journal of Natural Sciences Research, 3 (2), 83-97. Diperoleh dari http: //www.iiste.org/Journals/index.php/JNSR/artic le/download/4369/4432
Depkes RI. (2007). Laporan riset kesehatan dasar (RISKESDAS) 2007. Jakarta.

Devi, A.W., Ranjana, L., \& Laxmi, A. (2012). A survey to assess the knowledge, practice, and attitude on acute respiratory infection among mothers of under five children at $\mathrm{MCH}$ clinic, Ramghat, Pokhara, Nepal. International Journal of Nursing Education, 4 (1), 8-11.

Ferdous, F., Farzana, F.D., Ahmed, S., Das, S.K., Malek, M.A., Das, J., Faruque, A.S., \& Chisty, M.J. (2014). Mothers' perception and healthcare seeking behavior of pneumonia children in Rural Bangladesh. ISRN Family Medicine, 2014, 690315. doi: 10.1155/2014/6 90315.

Holland, D.E., Conlon, P.M., Rohlik, G.M., Gillard, K.L., Tomlinson, A.L., Raadt, D.M., \& Rhudy, L.M. (2014). Developing and testing a discharge planning decision support tool for hospitalized pediatric patients. J Spec Pediatr Nurs, 19 (2), 149-61. doi: 10.1111/jspn.12064.

Hoving, M.F.P \& Brand, L.P.B. (2013). Causes of recurrent pneumonia in children in a general hospital. J Paediatr Child Health, 49 (3), 208212. doi: 10.1111/jpc.12114.

Lees, L. (2013). The key principles of effective discharge planning. Nursing Times, 109 (03), 18-19. Diperoleh dari https://www.nursingtim es.net/Journals/2013/01/17/x/1/m/130122Effective-discharge-planning.pdf

Kozier, B., Erb, B., Berman, A., \& Snyder, S. (2005). Fundamental of nursing: Concept, process, and practice (Volume 1) (6th Ed.). New Jersey: Prentice Hall.

Morris, J., Winfield, L., \& Young, K. (2012). Registered nurses' perceptions of the discharge planning process for adult patients in an acute hospital. Journal of Nursing Education \& Practice, 2 (1), 28. Diperoleh dari http:// www.sciedu.ca/journal/index.php/jnep/article/ view/421 
Nantanda, R., Tumwine, J.K., Ndeezi, G., \& Ostergaard, M.S. (2013). Asthma and pneumonia among children less than five years with acute respiratory symptoms in Mulago hospital, Uganda: Evidence of under-diagnosis of asthma. PLoS ONE, 8 (11), e81562. doi:10.1371/journal.pone.0081562.

Nurhaeni, N., Sutadi, H., Rustina, Y., \& Supriyatno, B. (2011). Pemberdayaan keluarga pada anak balita pneumonia di rumah sakit: Persepsi perawat anak dan keluarga. Makara Kesehatan, 2 (15), 58-64.

Potter, P.A., \& Perry, A.G. (2006). Buku ajar fundamental keperawatan: Konsep, proses, dan praktik (Edisi 4). (Renata K., Dian E., Erni N., Alfriani H. \& Sati K., alih bahasa). Jakarta: EGC. (buku asli diterbitkan tahun 1997).
Shepperd, S., Lannin, N.A., Clemson, L.M., McCluskey, A., Cameron, I.D., \& Barras, S.L. (2013). Discharge planning from hospital to home. Cochrane Database Syst Rev. doi: 10.1002/14651858.

Syahrani, Santoso, \& Sayono. (2012). Pengaruh pendidikan kesehatan tentang penatalaksanaan ISPA terhadap pengetahuan dan keterampilan ibu merawat balita ISPA di rumah. Diperoleh dari http://ejournal.stikestelogorejo.ac.id.

Wahyuni, A., Nurrachmah, E., \& Gayatri, D. (2012). Kesiapan pulang pasien penyakit jantung koroner melalui penerapan discharge planning. Jurnal Keperawatan Indonesia, 15 (3), 151-158. 